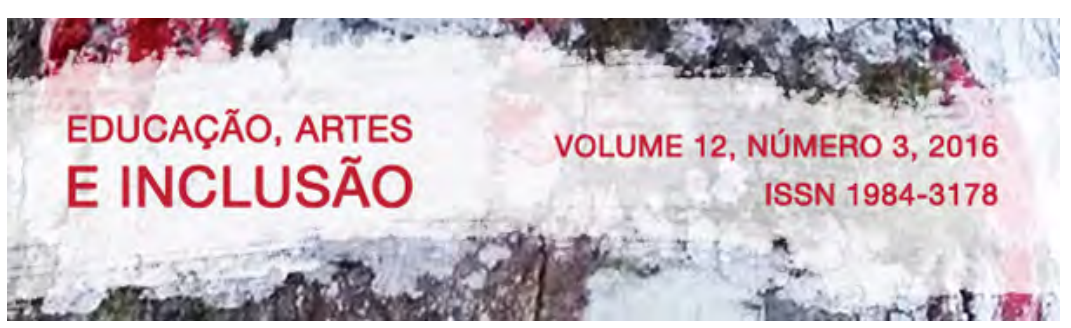

\title{
DAS TRIPAS À ARTE - PROCESSOS DE ENSINO EM ARTE- EDUCAÇÃO A PARTIR DAS OBRAS DE LENICE WEIS
}

\section{FROM THE INTESTINES TO ART - TEACHING PROCESSES IN ART- EDUCATION FROM THE WORKS OF ART BY LENICE WEIS}

DOI: http://dx.doi.org/10.5965/1984317812032016202

Netto de Souza - Unochapeco

\begin{abstract}
RESUMO
A presente pesquisa desenvolveu-se pela necessidade de reconhecer o espaço da arte-educação como um campo de reflexão sobre a arte local, explorando a poética e materiais usados pela artista Lenice Weis. A obra da artista nos remete ao processo colonizador da Região Oeste de Santa Catarina e práticas de diferentes grupos sociais. As relações entre o contexto local e a poética da artista geraram a experiência em arte-educação. Como metodologia, desenvolveu-se uma pesquisa bibliográfica sobre o histórico da região oeste de Santa Catarina, abordando questões que envolvem as culturas cabocla e colonizadora, bem como estudos sobre os principais pressupostos da arte-educação. Foi realizada entrevista semiestruturada com a artista com o objetivo de entender seu processo artístico e a influência da cultura em sua poética. A proposta foi desenvolvida em uma turma de $1^{\circ}$ ano do ensino médio de uma escola de educação básica no município de Chapecó/SC. A experiência em arteeducação com referenciais do contexto em que vivem trouxe para os/as estudantes novos conhecimentos e contribuiu para refletirem sobre aspectos da região em especial, as relações entre arte e cultura.
\end{abstract}

PALAVRAS-CHAVES: Arte-educação, Lenice Weis, Oeste catarinense.

\begin{abstract}
The present research was developed because of the need to recognize the space of art education as a field of reflection on the local art, exploring the poetics and materials used by the artist Lenice Weis. Her works of art brings us back to the colonizing process of the West Region of Santa Catarina and practices of different social groups. The relations between the local context and the poetics of the artist generated the experience in art education. The methodology developed a bibliographic research on the track record of the West Region of Santa Catarina, addressing issues involving cabocla colonizing cultures, as well as studies of the main assumptions of art education. A semistructured interview was made with the artist aiming to understand her artistic process and the influence of culture in her poetics. This proposal was developed in a class of 1st year high school at a basic education school in Chapecó, SC. The experience in art education with references from the context where they live in brought the students new knowledge and contributed to reflect on aspects of the region in particular, the relations between art and culture..
\end{abstract}

KEYWORDS: Art education; Lenice Weis; Western Santa Catarina. 


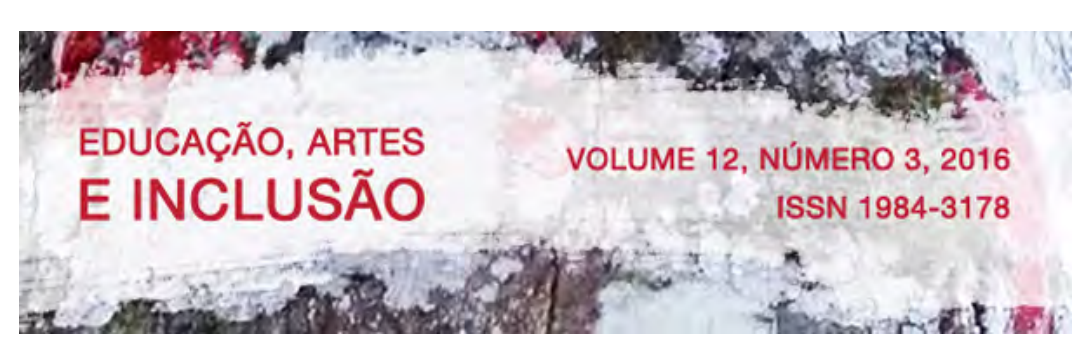

a experiência estética e o contexto local dos/das estudantes.

\section{O OESTE CATARINENSE E SUAS MANIFESTAÇÕES HISTÓRICO- CULTURAIS}

Enquanto o Oeste catarinense nas primeiras décadas de 1900 passava por grandes modificações com a chegada de imigrantes, ocupação do território, contato com as culturas indígena e cabocla (que aqui já viviam), o povoamento e organização das cidades, fluxo de diferentes mercadorias, enfim, um acelerado processo urbano e rural, em outras regiões do país, o processo artístico brasileiro já estava em progresso.

Foi somente nos anos de 1970-80 que a arte como expressão e representação formal ou acadêmica começa a ser desenvolvida no município de Chapecó. A partir disso, há algumas décadas a região oeste catarinense constituiu vários grupos e artistas que levam o nome do estado para outras regiões e países. Vale dizer que, neste fluxo artístico 'oestino', há artistas que buscam em suas origens, elementos para o desenvolvimento de suas poéticas, no caso em questão a artista Lenice Weis.

Com o propósito de refletir sobre as questões históricas da região Oeste de Santa Catarina, parte-se de uma visão voltada para as culturas cabocla e colonizadora, momento em que se iniciou a disputa de terras seguindo da colonização dos europeus a partir de 1910 e posteriormente a formação de uma cultura miscigenada de italianos, alemães, poloneses, caboclos e índios que foram os principais povos a se confrontarem no "velho oeste". Assim, tem-se o propósito de construir uma ponte entre essas culturas e as produções artísticas da região, com foco no trabalho da artista Lenice Weis.

Segundo Werlang (2002) o Oeste Catarinense foi colonizado posteriormente as outras regiões de Santa Catarina devido à chegada dos europeus ao Brasil através das navegações, assim o litoral catarinense foi o primeiro a ser colonizado. Já o povoamento da região oeste catarinense, de acordo com Poli (1989) citado por Werlang (2002), se deu a partir de três fases, "a fase indígena, que se deu até meados do século XIX; a fase cabocla, que a sucedeu e miscigenou-se com a indígena; e a fase da colonização", caracterizada pela vinda de imigrantes alemães, italianos e poloneses, organizados em torno dos projetos de colonização. (WERLANG, 2002 p. 58). 


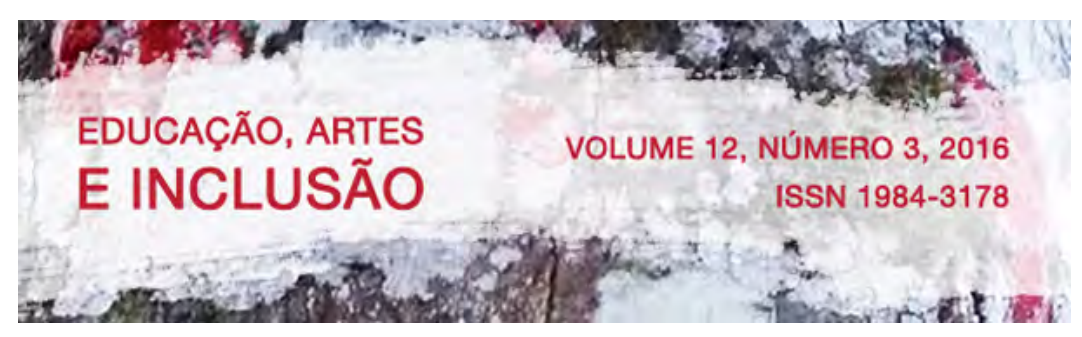

Vindos do Rio Grande do Sul, estado que também já estava com sua colonização visivelmente adiantada, e desse modo, não havia mais tantas terras disponíveis, esses colonizadores (a segunda geração dos advindos da Europa), vinham para o oeste catarinense, com a esperança de encontrar terras boas para colonizar. Em outra visão, conforme cita Renk (2004, p.20), o projeto do governo catarinense era incentivar a "[...] migração dos colonos do Rio Grande do Sul ao Oeste catarinense" como uma "estratégia de reprodução social camponesa, possibilitando-lhes adquirir terras a preço mais razoável." Vale dizer que havia muito incentivo das companhias colonizadoras que realizaram uma boa propaganda do lugar. O processo de posse de terra pelos vários grupos sociais foi marcado por disputas entre "[...] índios, caboclos, fazendeiros e empresas colonizadoras". (WERLANG, 2002, p.07).

Segundo dados do Centro de Memória do Oeste (CEOM), o processo de desbravamento da região oeste pelo caboclo não teria sido prejudicial aos indígenas que já habitavam a região, já que essas culturas se miscigenaram. O que gerou conflitos foi a ocorrência da "ação das empresas colonizadoras". Nesta etapa de colonização das terras 'oestinas' as diferenças culturais não foram respeitadas já que as empresas colonizadoras enalteciam a figura do colonizador, caracterizando-o como aquele que traria o desenvolvimento e o progresso para a região. (CEOM, 1995, p. 75).

Vale dizer que os colonizadores não sabiam o que iriam encontrar nessas terras. $\mathrm{Na}$ chegada de novos povos, ocorreu então, o confronto dessas diversas culturas, pois os colonizadores trouxeram uma forma de viver muito diferente da vivida por índios e caboclos, e não ouve nenhum processo de adaptação, ou alguma preocupação em unir essas culturas.

Um dos primeiros pontos de atrito da Companhia com os intrusos, além da ocupação da área, era a criação de animais soltos, sem o uso de cercas nas terras de criar. No período pré-colonização, com a abundância de terras, a lavoura ficava distante da casa e criação de animais soltos não prejudicava a primeira área. Este tipo de atividade exige a amplitude de espaço físico, o que só era possível numa área sem concorrência. (CEOM, 2006, p. 42).

Os caboclos não se adaptaram aos costumes dos 'novos' grupos sociais. Eram chamados pela Companhia de intrusos, uma vez que não dispunham de registros das terras que ocupavam. Neste sentido buscou-se o significado do termo 'intruso' e segundo Ramos 


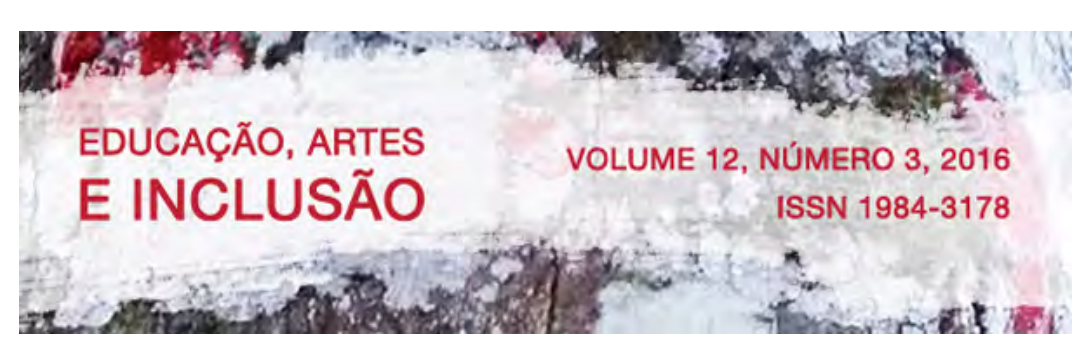

(2011, p. 479) a palavra refere-se a: “[...] que ou quem se introduziu sem direito, sem autorização ou sem consentimento".

A partir desse conceito levanta-se o seguinte questionamento: de quem eram os direitos desta terra a qual residimos hoje? A história mostra que os governos não estavam interessados em tais questionamentos, apenas nos seus próprios interesses, o que resultou na sociedade que temos hoje, onde grupos sociais como negros, indígenas e caboclos constituem a classe social marginalizada, ainda que nas últimas décadas tenham ocorrido mudanças em relação ao empoderamento desses grupos sociais que não cabe aqui ignorarmos.

Também em relação aos seus modos de vida, constituída principalmente pela autossuficiência, ou seja, não havia preocupação com a produção excedente e o acúmulo de bens, os caboclos eram vistos como conformados e por vezes preguiçosos. Em relação ao cultivo de alimentos e a criação de animais também o caboclo foi visto como 'povo atrasado'. Muito antes da chegada dos colonizadores e depois, com o desenvolvimento da agroindústria, a criação de suínos era prática na região pelos caboclos. Segundo relato do senhor Silva, apresentado por Marcon,

Você vê que a invernada que tinha, o potreirinho era daqui do rio, na costa do rio Chapecó. Aí tudo criava assim sorto. Marcava, tinha um sinal, a marca [...]. Uns queimava, outros assinavam na oreia; o porco erra assinalado na oreia. Cortava, tirava uma lasca, outro pegava um cartucho de espingarda e batia assim e furava. Um tem um furo, outro tem dois, outro tem três furo, outro tem corte, outro oreia lascada. Era assim, má, porco, rapaiz! (MARCON, 2003, p.163).

Conforme o registro acima, o caboclo tinha um costume de criar porco de forma que o animal permanecia solto na natureza e cada pessoa marcava o seu animal de forma que pudessem reconhecê-los (por suas características físicas, a cor, uma mancha ou pinta, etc). Pode-se ver, portanto, que havia respeito a propriedade, cada família abatia somente o animal que lhe pertencia, mesmo tendo vários porcos, de donos diferentes, soltos, compartilhando o mesmo espaço.

Segundo Veridiano P. da Silva, os caboclos faziam uso extensivo das terras, criando animais soltos e não tendo problemas entre os vizinhos, visto que partilhavam de uma mesma percepção. A forma de criação dos porcos aponta, portanto, para as relações dos caboclos com a terra e com os vizinhos e, ao fazer referência a 


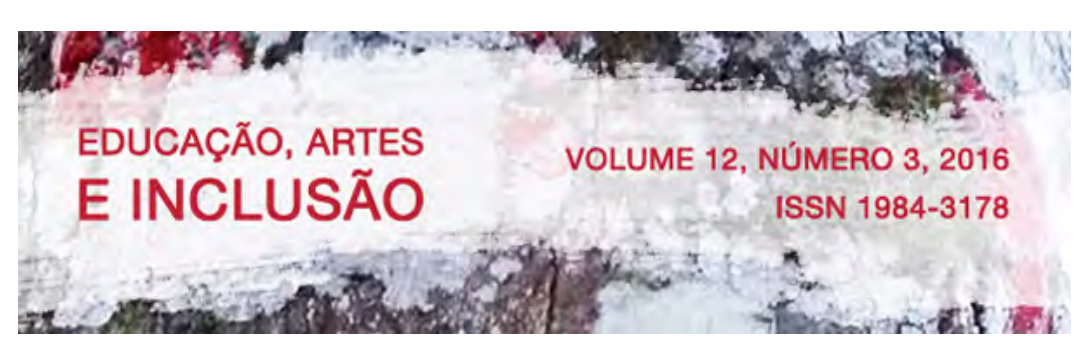

abundância de porcos, aponta para um importante componente na dieta alimentar, especialmente a carne e a banha. (MARCON, 2003, p. $165-166$ ).

Ainda de acordo com os estudos do autor citado, para conservar o alimento (pois não havia refrigeradores) a carne era cozida e frita em meio à banha. Era armazenada desse modo, em latas fechadas, permitindo a sua conservação por longo tempo (MARCON, 2003). É interessante a forma como os caboclos da região, especialmente
Feliciana Almeida, tratam os animais: cada um tem sua história, suas
manias e reações, seu nome etc. O ato de nomear os animais, dando-lhes
um tratamento peculiar e individualizado, expressa as relações profundas
e subjetivas entre ambos, mostrando que é necessário preservar as
individualidades. Deixar os animais distantes das casas, ou fechados em
cercas, significava, pelo menos no passado, alterar essas relações.
Atualmente, devido às transformações que se processaram, os caboclos
mantêm os animais dentro de áreas cercadas. (MARCON, 2003, p. 171 -
172).

É possível perceber que o caboclo possuía, portanto, costumes próprios, construídos em sua cultura. A natureza tinha sentido de local para sobrevivência e vida em harmonia. Os caboclos faziam suas lavouras em meios alternados, ou seja, a cada um ou dois anos, mudavam sua lavoura de local, permitindo que a terra já cultivada pudesse se recuperar. Nessa dinâmica, também suas moradas eram transitórias. Na visão de Marcon (2003), esses grupos sociais não compartilhavam das formas de vida dos colonizadores, que compravam a terra, preparavam-na para o plantio com queimadas e roçadas, colhendo e preparando novos plantios, sem deixar a 'terra descansar'. Construíam sua residência em um ponto fixo e criavam seus animais em cercados.

A visão de desenvolvimento e de progresso colonizador, a exploração do ambiente e o modo como criavam os bichos, seguindo a visão cabocla, era um desrespeito aos mandamentos da natureza segundo os ditos de São João Maria (monge que percorria a região dando ensinamentos sobre religião e natureza). Entre uns dos mandamentos está: "Quem descasca a cintura das árvores para secá-las, também vai encurtando sua vida. A árvore é quase bicho. E bicho é quase gente". (MARCON, 2003, p. 287). 


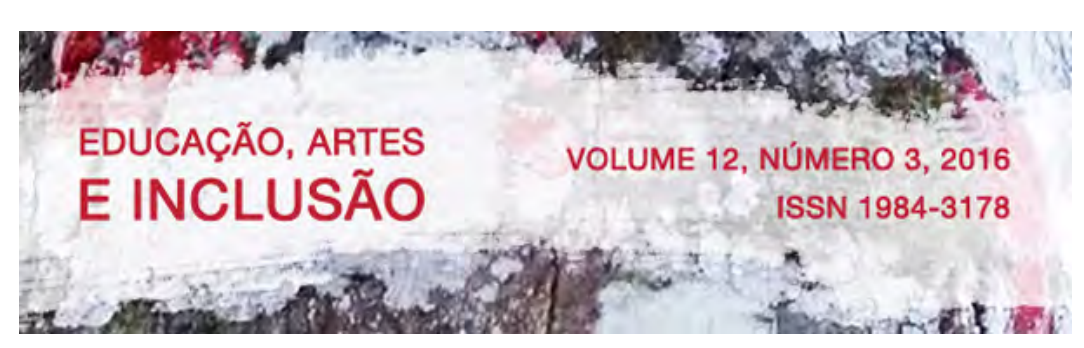

Tal sistema, que foi amplamente difundido no Oeste de Santa Catarina, desde a fundação das agroindústrias da região, a ponto de tornar-se o sistema dominante até a atualidade, acabava com a autonomia dos produtores rurais, prometendo maior produtividade e lucratividade. (ONGHERO, 2012, p.131).

Grande parte das pessoas que aqui habitaram, tiveram a experiência de ter em suas propriedades o porco criado para o consumo, porém raramente se encontra algumas pequenas propriedades que ainda mantêm essa cultura, pois muitas famílias adquiriram o método agroindustrial, ao passo que, outras optaram por outros meios de difundir-se economicamente.

Antes das agroindústrias abrangerem praticamente toda a região muitos agricultores criavam porcos chamados 'comuns', pois não advinham de um desenvolvimento genético. Hoje essa cultura praticamente se desfez e a região, através da industrialização, é uma das maiores produtoras de suínos do mundo. Com a implantação da visão do colonizador e no processo de industrialização, a região oeste passa por profundas modificações em seus aspectos econômicos, sociais, políticos e religiosos.

\section{AS INFLUÊNCIAS HistóRICO-CULTURAIS E A POÉTICA ARTíSTICA DE LENICE WEIS}

Lenice Ines Weis nasceu em 23 de março de 1959 na cidade de Itapiranga (na língua Tupi 'itá' - pedra e 'pyrang'- vermelha), localizada no extremo oeste de Santa Catarina. Formada por imigrantes alemães nos anos de 1920, atualmente, a cidade tem como base econômica a agropecuária, a criação de aves, suínos e gado leiteiro. Nesta cidade Lenice viveu com sua família, imigrantes alemães, até os 20 anos de idade.

Como principais influências para sua formação estética Lenice cita seu avô materno, Alfredo Shtal que era dentista e também fazia parte de um grupo de teatro, no qual era diretor. Seu pai Pedro Lindolfo Weis, comerciante e fotógrafo, nas horas vagas tocava violino. Segundo Lenice, seu pai "mostrava-lhe uma pedra, folha ou o céu e dizia, olha, perceba os detalhes, veja como está diferente!’. Lenice comenta sobre as habilidades de sua mãe Wilma Teresinha Weis, no corte e costura e na culinária. A mãe acreditava na importância da música e do teatro na formação dos filhos. Ainda de acordo com a artista, seus oito irmãos foram 


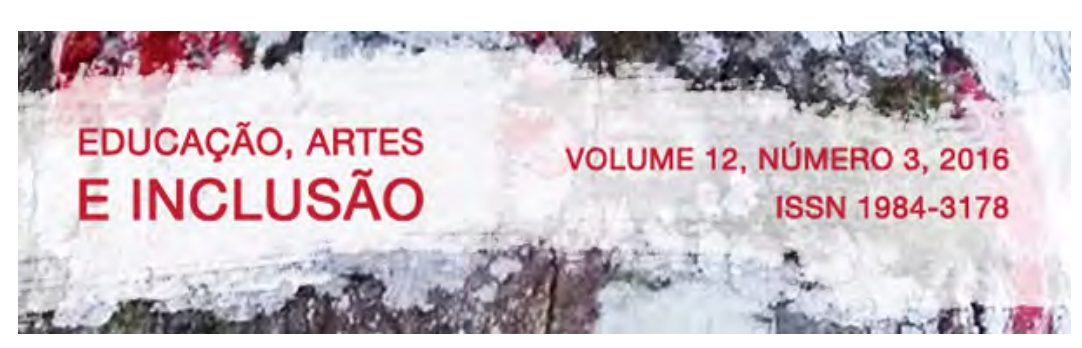

cúmplices de atividades na infância (que ela transformaria em produção artística futuramente). As brincadeiras nos dias de matança de porcos entre tantos momentos a influenciaram no desenvolvimento de um comportamento lúdico e criativo.

O inicio de seu trabalho com os elementos culturais ocorre quando seu professor do curso de graduação em Licenciatura Plena em Educação Artística, cursado na Universidade Estadual de Santa Catarina (UDESC), em 1979, solicitou que fizesse desenhos tendo a infância como referência. Para Lenice, em sua memória havia formas que lembravam os órgãos internos do porco.

\begin{abstract}
A imagem das entranhas de um porco, uma das mais fortes lembranças de infância de Lenice Weis, é responsável pela descoberta de seu caminho artístico. Quando ela desperta para a arte, já no curso das Artes Plásticas, passa a se inspirar nas formas, nas cores e nos encaixes dos órgãos internos do animal, que ela via sendo morto para se transformar em carne e linguiça. 'Não é protesto. Utilizo essas formas pela sua plasticidade, que é perfeita', diz a artista. (MATTOS, 2014, p. 94).
\end{abstract}

Surgem as primeiras experiências com as referências culturais na pintura. São formas orgânicas e livres. Uma mistura de tintas (óleo e acrílica), de cores, de técnicas e de elementos que parecem estar envolvidos por uma fina camada de pele.

No manuseio das vísceras dos porcos, a artista realiza um tratamento a base de formol para que não apodreçam e percam a forma, após os elementos passam por um processo de tingimento com o uso de álcool e anilina colorida. Expostas em diferentes recipientes, a 'arte visceral' de Lenice causa espanto e encantamento conforme registrado no blog da artista, em um poema de Silvério da Costa: "Estou, visceralmente, encantado com as vísceras! Elas me comovem, e me movem, e me levam ao delírio, porque fogem do enquadramento para assumirem a verdade... do mundo!".

Em 2010, na obra composta de flores feitas com as tripas, Lenice sai do espaço bidimensional das telas e cria uma instalação na praça central da cidade de Chapecó. A obra "atraia moscas e repelia seres humanos", diz a artista. As vísceras transformam-se em rosas (elemento símbolo da cidade de Chapecó). Sua instalação 'Cidade das Rosas' não faz somente uma referência a uma antiga denominação da cidade, mas propõe pensar em todos os âmbitos que as rosas feitas de tripas de suínos (elementos presentes na intervenção) abrangem. 


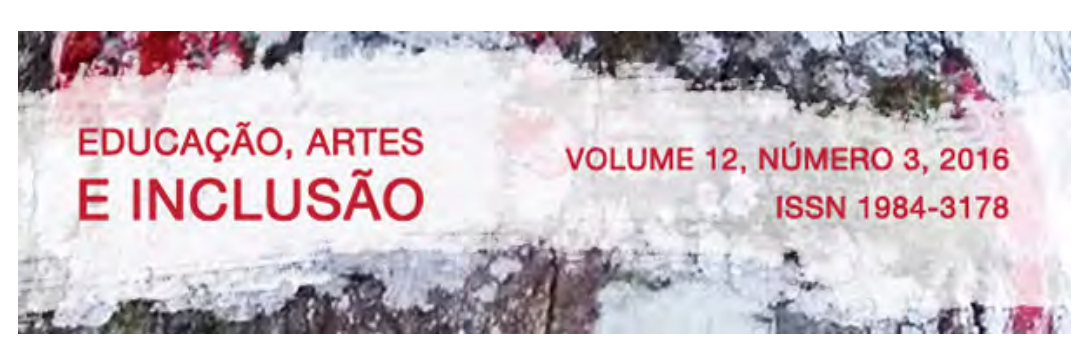

Ao realizar instalações e intervenções urbanas, num segundo momento de sua trajetória artística, o que muda é apenas o material utilizado. Em vez de tintas reproduzindo as formas na tela, os próprios órgãos e vísceras do animal é que são a matéria-prima, depois de passarem por um tratamento que inclui limpeza e assepsia e, em seguida, um banho de cor, todos processos que ela mesma criou e executa. (MATTOS, 2014, p. 94).

Neste sentido, o trabalho de Lenice ganha forma por meio da matéria orgânica que vai tratar muito além de questões pertinentes aos seus momentos criativos da infância, embora seja esta a proposta da artista. Segundo o curador Charles Narlock (2010) em seu texto intitulado 'Intervenção Urbana', publicado no portfólio da artista,

De vida, morte e principalmente realidade se estrutura poeticamente. Como a insatisfação com seu entorno, o que parece mover a artista, também a obra turba o ambiente e quem nele vive. Um incômodo jardim de órgãos. Suas flores atraem moscas e repelem seres humanos. Possuem fétido e inconveniente odor, ou, talvez, um cheiro corriqueiro que apenas mudou de lugar, intrometendo-se nos caminhos dos transeuntes da praça principal da cidade ${ }^{1}$.

Em entrevista Lenice diz é de seu costume permanecer próxima ao público em suas exposições, para ouvir o que as pessoas pensam e como reagem ao seu trabalho. Assim já presenciou várias indagações, como: “[...] essa artista deve estar fazendo um protesto contra a matança de porcos" ou "[...] essa artista deve trabalhar com anatomia". Contudo, a artista diz que busca representar e refletir em seu trabalho momentos 'mágicos', de extrema ludicidade, que vivenciou em sua infância.

O abate (ou matança e preparação da carne para consumo) de um porco é um evento dramático e cruel, não é nada agradável de ser presenciado. Contudo, na lúdica imaginação de Lenice, os órgãos do animal transformavam-se em elementos para brincadeiras entre os irmãos. As formas e as cores das vísceras eram enigmáticas e chamavam a sua atenção. Para Costa (2015), em seu texto "Teorias da Arte":

[...] antes do artista produzir a sua obra ele ainda não possui a emoção estética que a sua obra produzirá na audiência e em si mesmo. O que ele possui é uma "excitação emocional", um sentimento indefinido e incompreensível. Na medida em que ele utiliza sua imaginação e

\footnotetext{
${ }^{1}$ As informações aqui apresentadas foram extraídas de texto presente no portfólio da artista Lenice Weis, em que constam diversos textos elaborados por curadores.
} 


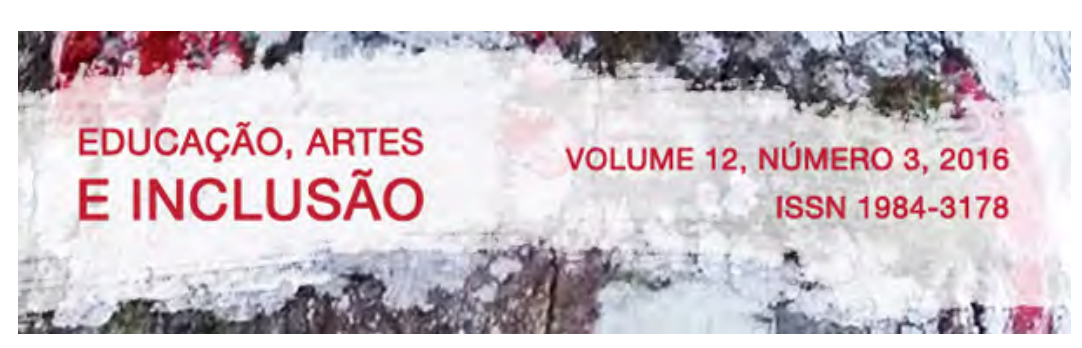

pensamento planejando e produzindo a obra de arte, ele consegue reconhecer melhor a natureza de suas emoções, defini-las, refiná-las, clarifica-las e articulá-las em sua relação com seus objetos. Essas emoções assim classificadas são, por sua vez, imaginativamente e, reconhecidas enquanto tais pela audiência capaz de apreciar a obra de arte. (s.p.).

Levando em conta a experiência de cada público, compreende-se, portanto, que a recepção desses para com a obra de Lenice pode proporcionar diversas reações que vão desde a curiosidade e o espanto até indagações sobre sua motivação e significados.

Refletir sobre a poética da artista permite conhecer e interpretar a realidade social ao qual a região oeste catarinense está inserida.

As práticas educativas surgem de mobilizações sociais, pedagógicas, filosóficas, e, no caso de arte, também artísticas e estéticas. Quando caracterizadas em seus diferentes momentos históricos, ajudam a compreender melhor a questão do processo educacional e sua relação com a própria vida. (FERRAZ; FUSARI, 1993, p. 27).

Independente da intenção da criação da sua obra percebe-se a relação entre o seu trabalho e a realidade social, um contexto que envolve a cultura e em outra visão, o meio de sobrevivência e renda de muitas comunidades. O modo como ainda jovem Lenice percebia a arte, motivada pela íntima relação familiar e pelo contexto cultural em que vivia, é visto nesta pesquisa como um tema que pode se desdobrar em novos conhecimentos acerca da arte e da sua relação com a vida humana. Vale dizer, que a produção artística de Lenice Weis contribui para o panorama das artes com a desconstrução ou ainda, a ressignificação da técnica da pintura e uso de elementos não convencionais.

\section{A IMPORTÂNCIA DO CONTEXTO LOCAL NA ARTE-EDUCAÇÃo}

Segundo a educadora Ana Mae Barbosa o ensino de artes ainda é pouco valorizado porque desde o princípio, quando as primeiras escolas surgiram, as disciplinas especificamente voltadas ao fazer técnico eram vistas como necessárias e importantes para a sociedade. A disciplina Artes tinha como compromisso 'complementar' às outras. "O ensino 


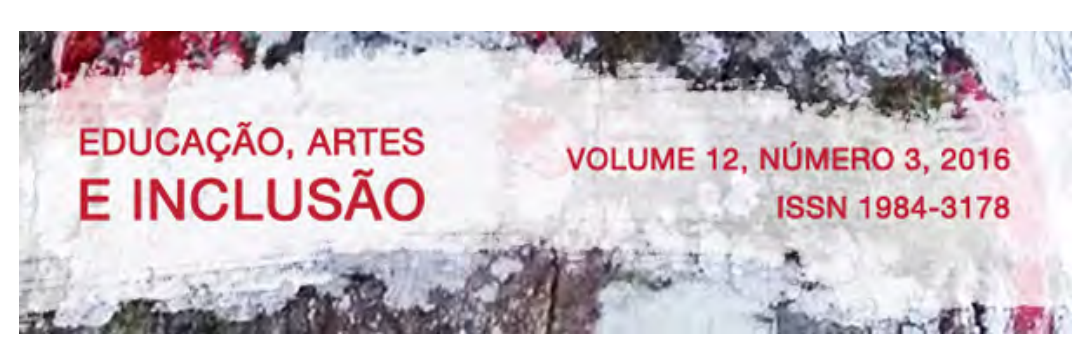

artístico no Brasil só agora, e muito lentamente, se vem libertando do acirrado preconceito com o qual a cultura brasileira o cercou durante quase 150 anos que sucederam a sua implantação" (BARBOSA, 2002, p. 15).

Há, no cenário educacional brasileiro alguns descompassos que acompanham o ensino da arte. Pode-se citar como exemplo, a ideia da arte como momento de 'relaxamento' ou 'recreação' entre as atividades mais 'sérias' e 'importantes', ou ainda, a disciplina de artes como um 'suporte' para o aprendizado de outras matérias.

É possível dizer ainda que há no contexto atual da educação em arte, de modo geral, acesso limitado às exposições de artistas locais, lacunas na educação básica sobre a importância da arte na formação cidadã, cultural e estética do/a estudante, falta de incentivos para a apreciação estética e apoio para pesquisas na área artística, entre outras questões.

Entende-se que, para que haja a ressignificação do ensino da arte é necessário que ocorram mudanças nos planejamentos e currículos escolares, sobretudo nas escolhas pedagógicas que priorizem um processo de ensino e aprendizagem no qual os/as estudantes considerem (e percebam) o objeto de estudo como algo significativo, de relevância histórica e cultural.

\begin{abstract}
No que se refere à história da arte brasileira, o enfoque dado não segue nenhum autor especial, mas tão somente a sequência dos grandes marcos até o momento atual. Entretanto, faz-se necessário conhecer o processo de modernização na arte e seus desdobramentos na arte atual, além de identificar as raízes locais em diálogo com as manifestações da arte hegemônica. (SANTA CATARINA, 1998, p. 199).
\end{abstract}

Para a artista e professora Elisa Iop (2002, p. 16), “[...] na sociedade pós-moderna, devido aos sistemas e processos que se dirigem à massificação, os educandos têm tido pouca oportunidade de desenvolver processos criativos tendo como referência o contexto cultural no qual estão inseridos".

De acordo com os Parâmetros Curriculares Nacionais em Arte: 


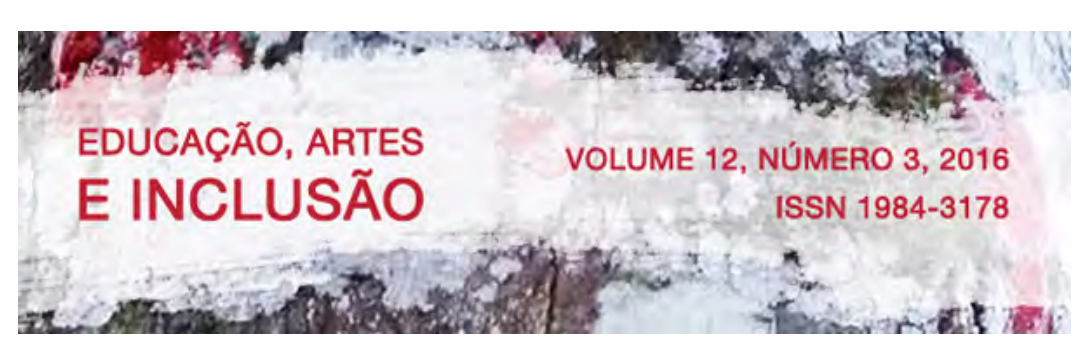

[...] aprender arte envolve não apenas uma atividade de produção artística pelos alunos, mas também a conquista da significação do que fazem, pelo desenvolvimento da percepção estética, alimentada pelo contato com o fenômeno artístico visto como objeto de cultura através da história e como conjunto organizado de relações formais [...]. Ao fazer e conhecer arte o aluno percorre trajetos de aprendizagem que propiciam conhecimentos específicos sobre sua relação com o mundo. (BRASIL, 1998, p.44).

Preceitos da Proposta Curricular do Estado de Santa Catarina estão alinhados com a questão destacada pelos PCN-Arte:

O contato com sua identificação cultural possibilita-lhe valorizar as suas raízes histórico-culturais, permitindo-lhe uma visão mais ampla de suas vivências como extensão da existência humana. É na socialização e na humanização que o indivíduo desenvolve o seu processo criativo [...]. (SANTA CATARINA, 1998, p. 194).

Ao proporcionar reflexões e vivências sobre a cultura local, oportuniza-se ao estudante estabelecer relações com o lugar em que vive, criam-se novas possibilidades de representação e de expressão. Por outro lado, é relevante que o professor enfatize que a produção artística não se dá pelo acaso e que ao criar, o artista busca dar sentido às suas emoções e ideias. Desse modo, ao situar o/a estudante no contexto da criação do artista, é possível tornar o mundo das artes mais 'palpável', significativo, pois é por meio da interação com o objeto de estudo que se chegará à compreensão conceitual da obra.

Como citado por Barbosa (2009) é necessário levar ao estudante a compreensão do contexto histórico em que o artista está inserido, suas motivações e a relação que o mesmo estabelece com a realidade. Contribuindo, de acordo com Ferraz e Fusari (1993 p.18) “é preciso verificar como tais relações culturais mobilizam valores, concepções de mundo, de ser humanos, de gosto e de grupos sociais".

No desdobramento de atividades que incluem a história da arte, o contexto do artista local e as vivências estéticas e artísticas em sala de aula, conforme citado por Elisa Iop (2002, p. 23) “[...] faz-se necessário, a 'priori', abordar os códigos estéticos e culturais nos quais o educando está inserido.” Contudo, é importante estabelecer uma conexão com os grandes 


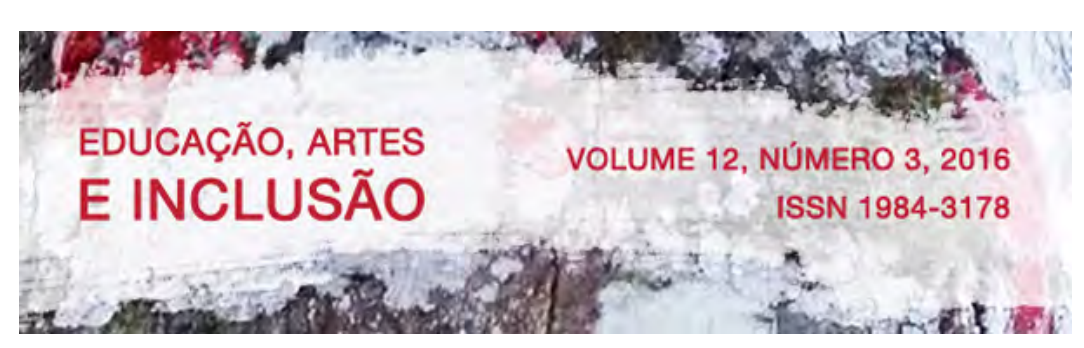

nomes artísticos, com os fatos históricos onde a arte se manifestou e as produções artísticas que tal sociedade produz, pois ainda de acordo com a autora citada:

[...] o ensino da arte deve possibilitar o acesso aos códigos estéticos e culturais à compreensão da linguagem visual, cênica, corporal e musical, o que possibilitará uma maior conscientização em torno de nossos valores culturais, bem como a compreensão da arte produzida em outras épocas culturas e contextos [...]. (IOP, 2002, p.58).

Complementando a questão levantada, de acordo com Barbosa (2009, p. 5) "Não é possível o desenvolvimento de uma cultura sem o desenvolvimento das suas formas artísticas". Nesse sentindo, a produção artística local pode proporcionar ao educando possibilidades no desenvolvimento de experiências que resultem, entre outras questões, de ensinamentos sobre novos e importantes modos de olhar e ver a realidade.

\section{MÉTODO}

Em relação às escolhas metodológicas esta pesquisa possui caráter qualitativo. Sendo que uma das características desse tipo de pesquisa segundo Silva e Menezes (2005, p.20) "o ambiente natural é a fonte direta para coleta de dados e o pesquisador é o instrumento chave". Neste sentido, a escola constitui-se o ambiente da presente pesquisa, sendo os dados o resultado das atividades teórico-práticas realizadas com os/as educandos/as.

Como abordagem a presente pesquisa se enquadra em uma investigação exploratória, pois, de acordo com Gil $(1999$, p.49) "as pesquisas exploratórias constituem a primeira etapa de uma pesquisa mais ampla”. Vale dizer que como percurso científico, as autoras pretendem aprofundar as questões aqui apresentadas e os resultados aqui demonstrados, no futuro, em outros níveis de formação, em uma especialização ou em um programa de pós-graduação em nível de mestrado. Ainda em relação à metodologia, como procedimentos usou-se revisão bibliográfica concernente aos temas tratados; contato com a artista Lenice Weis e seu universo artístico; pesquisas em artigos e outros materiais disponibilizados pela Internet.

A abordagem triangular de Ana Mae Barbosa fundamentou metodologicamente as atividades, pois possibilitou a articulação entre o estudo sobre o universo da arte, as 


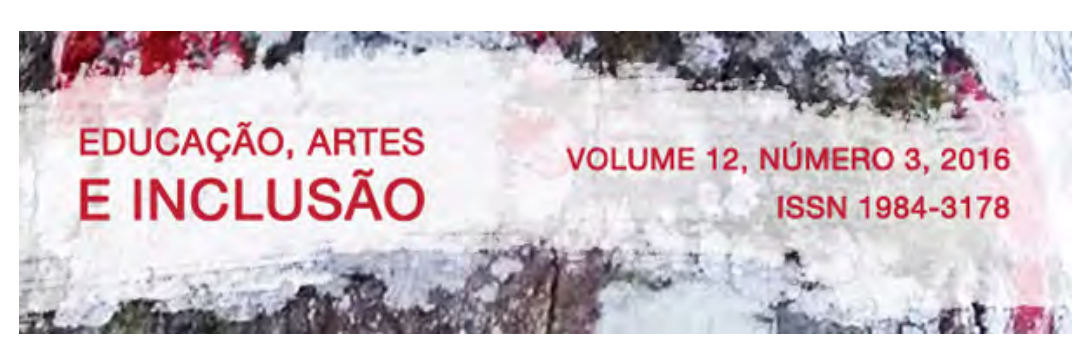

experiências vivenciadas pelos estudantes e a leitura do fazer. Ana Mae está entre as educadoras pioneiras da inserção da arte na escola é defensora do ensinar através da relação da obra de arte com a realidade do aluno e a importância da imagem neste campo do ensino. Ressaltam-se neste sentido, os estudos de Elisa Iop que também enfatizam que o educando deve conhecer e compreender a realidade em que vive e também da importância da valorização da produção artística local.

A proposta foi aplicada em uma turma de $1^{\circ}$ ano do ensino médio em uma escola estadual de ensino no município de Chapecó - SC. A turma era composta com 12 a 16 estudantes em idade média de 16 e 17 anos. No total foram 10 horas/aula de atividades desenvolvidas.

Destaca-se que ao analisar os dados coletados deu-se importância para as características criativas, perceptivas e cognitivas das atividades desenvolvidas pelos/as educandos/as sem, contudo realizar julgamento de ordem estética. Assim, buscou-se aprofundar a importância de valorizar o artista local nas escolas e a relevância de conhecer a própria cultura para compreender melhor a arte e assim, resultar em um olhar mais sensibilizado e crítico, enaltecendo as produções artísticas.

\section{A PRÁTICA PEDAGÓGICA E SUAS REFLEXÕES}

Nessa seção serão abordadas questões referentes às práticas desenvolvidas a partir da temática apresentada. Como ponto de partida, reitera-se a importância das aulas de arte como um percurso onde o/a estudante seja estimulado a participar e interagir com as experiências propostas, estabelecendo relações com a criação, interpretação e expressão. Ou seja, o/a estudante conhece, interpreta e se posiciona frente a novos significados e conceitos.

A partir do exposto, deu-se início às atividades com os/as estudantes ${ }^{2}$, primeiramente, contextualizando aspectos da região oeste de Santa Catarina, em especial, relacionando seu desenvolvimento a partir de aspectos históricos, econômicos e socioculturais.

\footnotetext{
${ }^{2}$ Escola de Educação Básica Zélia Scharf, no município de Chapecó-SC.
} 


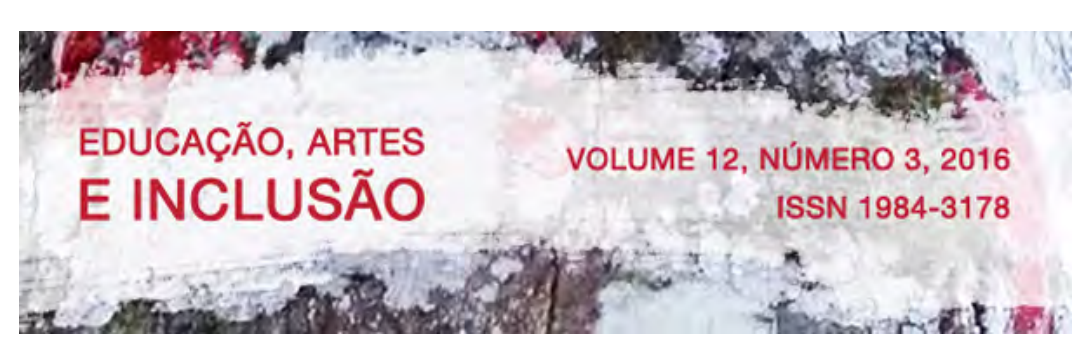

Neste contexto e com apropriação de imagens, foram destacadas questões relativas à produção de porcos na região, esclarecendo as técnicas ou os modos de criação dos animais conforme os grupos étnicos, de acordo como explanado na sessão 2 deste trabalho.

Após as explanações gerais, que geraram vários questionamentos, deu-se início aos conteúdos relacionados à artista Lenice Weis, expondo sua poética e linguagem artística. Realizou-se leitura de imagens de obras da artista tendo como suporte teórico, o texto do crítico de arte Norberto Stori (1995), com o título "Imaginação - Criação - Expressão".

Após essa atividade, as/aos estudantes elaboraram um memorial descritivo em que deviam registrar as suas primeiras percepções a partir do tema trabalhado para, na sequência, dar continuidade as atividades. Ferraz e Fusari (1993, p.20) dizem que "o professor que está trabalhando com a arte precisa conhecer as noções e os fazeres artísticos e estéticos dos estudantes e verificar que medida pode auxiliar na diversificação sensível e cognitiva dos mesmos". Como referência artística, foi mostrado aos estudantes a obra intitulada 'Cidade das Rosas' de 2010, em que a artista 'molda' flores com as tripas de porcos, conforme a Figura 1.

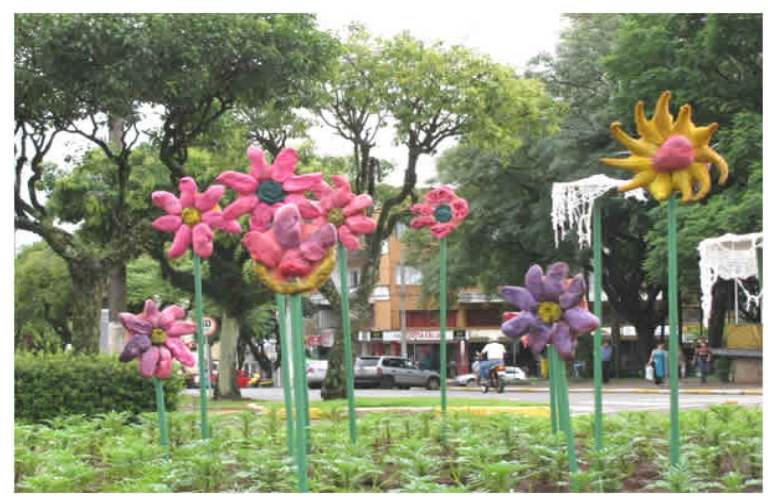

Figura 1: Cidade das Rosas (2010). Intervenção da artista Lenice Weis.

Fonte: Portfólio da Artista Lenice Weis.

Em grupos de três a quatro componentes, foi solicitado que elaborassem um estudo para a pintura, tendo como referenciais o histórico da região oeste e as obra da artista. Após um esboço do desenho em um suporte de papel, os/as estudantes usaram a técnica de stencil e 


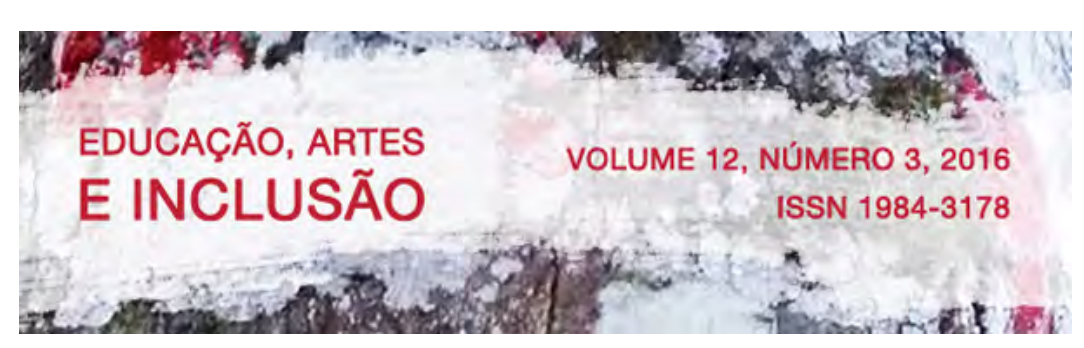

sobre a pintura, foram coladas as tripas $\operatorname{secas}^{3}$. A atividade teve como motivação a utilização da mesma técnica usada pela artista.

Assim, dois grupos se dispuseram a representar em seus esboços, a criação de porcos segundo a visão da cultura cabocla e um grupo, a cultura do colonizador. Os/as estudantes estabeleceram uma relação mais próxima com a cultura do caboclo, isso pode ter ocorrido de modo instintivo, pelos próprios referenciais culturais ou ainda pela curiosidade gerada durante a explanação teórica.

É importante registar que quando os/as estudantes tiveram contato com a tripa seca, as reações foram múltiplas. Entre repúdio e espanto, tiveram dificuldades de aceitar o material. Porém aos poucos foram se 'acostumando' com a ideia, e comentários que esse material poderia estragar o trabalho foram surgindo. Por fim os/as estudantes inseriram, timidamente, alguns pedaços de tripa na pintura.

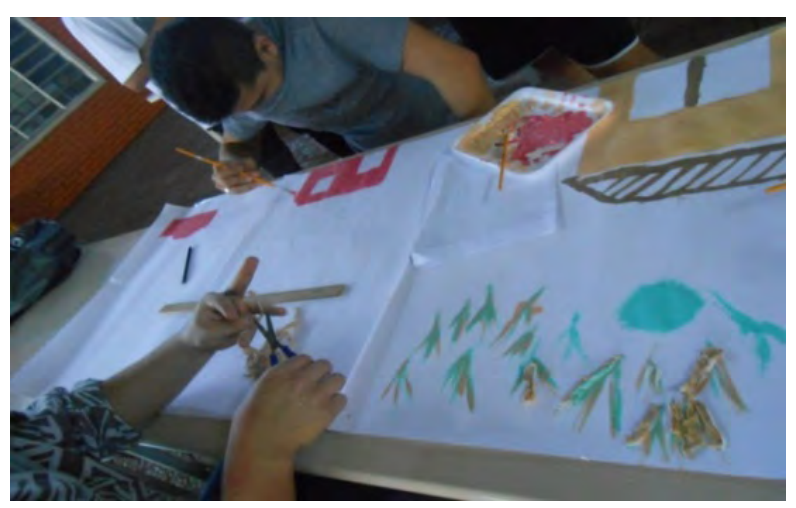

Figura 2 - Processo da produção de painel.

Fonte: Acervo Pessoal (2015).

Embora os estudantes tivessem recebido embasamento teórico sobre o trabalho da artista, o contato com o material foi difícil e também ativou preconceitos já estabelecidos. Quando os/as estudantes mencionam que a tripa estragaria o trabalho, foi questionado o porquê, então argumentaram que o material 'cheira mal', era feio e de difícil manuseio. Assim percebeu-se a necessidade de desmistificar questões relativas ao conceito de 'belo' na arte.

\footnotetext{
${ }^{3} \mathrm{Na}$ região oeste é muito comum encontrar em lojas de artigos agropecuários, tripas secas que servem como invólucro na preparação de embutidos como salame e linguiça.
} 


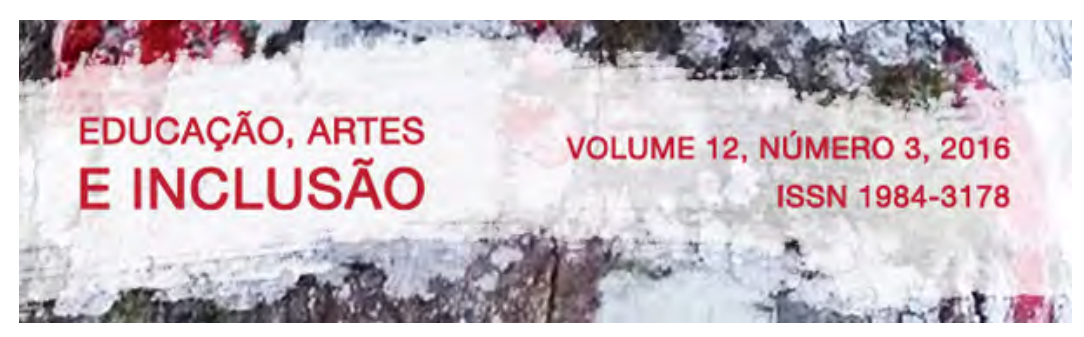

Após a compreensão, ressaltamos a todos que esse material era o elemento utilizado pela artista em questão, e ao utilizarem dariam ‘sentido' ao trabalho artístico realizado.

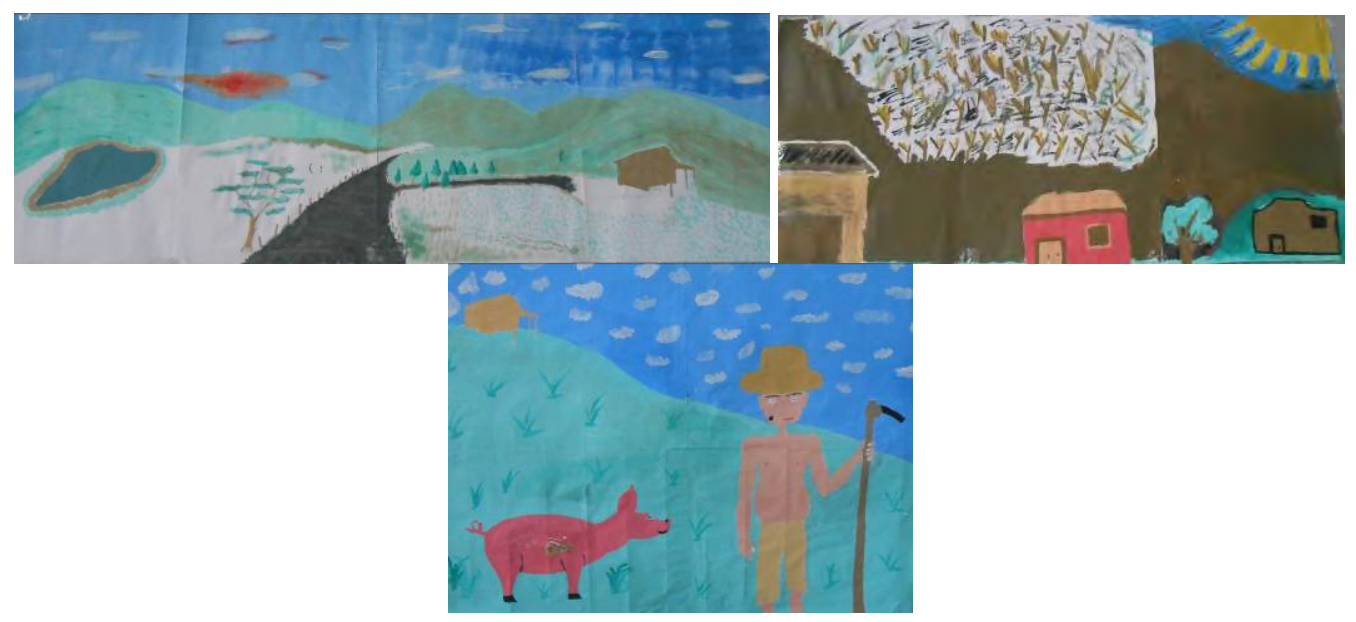

Figura 3: Pinturas finalizadas - Grupos 1,2 e 3.

Fonte: Acervo Pessoal (2015).

$\mathrm{Na}$ realização deste trabalho os/as estudantes foram incentivados a buscar referências tanto na obra da artista quanto na exposição teórica sobre o contexto local. Dando continuidade aos estudos, após o término das pinturas foi proposto aos estudantes a realização de uma intervenção na escola, usando a linguagem da performance e do happening, as quais foram contextualizadas a partir de suas caraterísticas principais. As apresentações e intervenções foram realizadas entre as trocas de aula e realizadas nas salas de aula próximas ao espaço de circulação.

O grupo 1 se envolveu com a realização de uma performance coletiva. A atividade planejada por eles foi de um desenho, usando giz colorido, de uma grande flor, no espaço de convívio e recreação da escola. Usando como inspiração a obra da artista, os/as estudantes 'cobriam' o desenho com tiras de tripas. Como já haviam trabalhado com as tripas, pode-se perceber que já estavam familiarizados com o elemento estético, ao contrário de seus colegas de outras turmas que manifestavam repúdio ao elemento. $\mathrm{O}$ processo criativo se dá no envolvimento de cada um deles e como o público (colegas da escola), percebe o trabalho, conforme figura 4. 

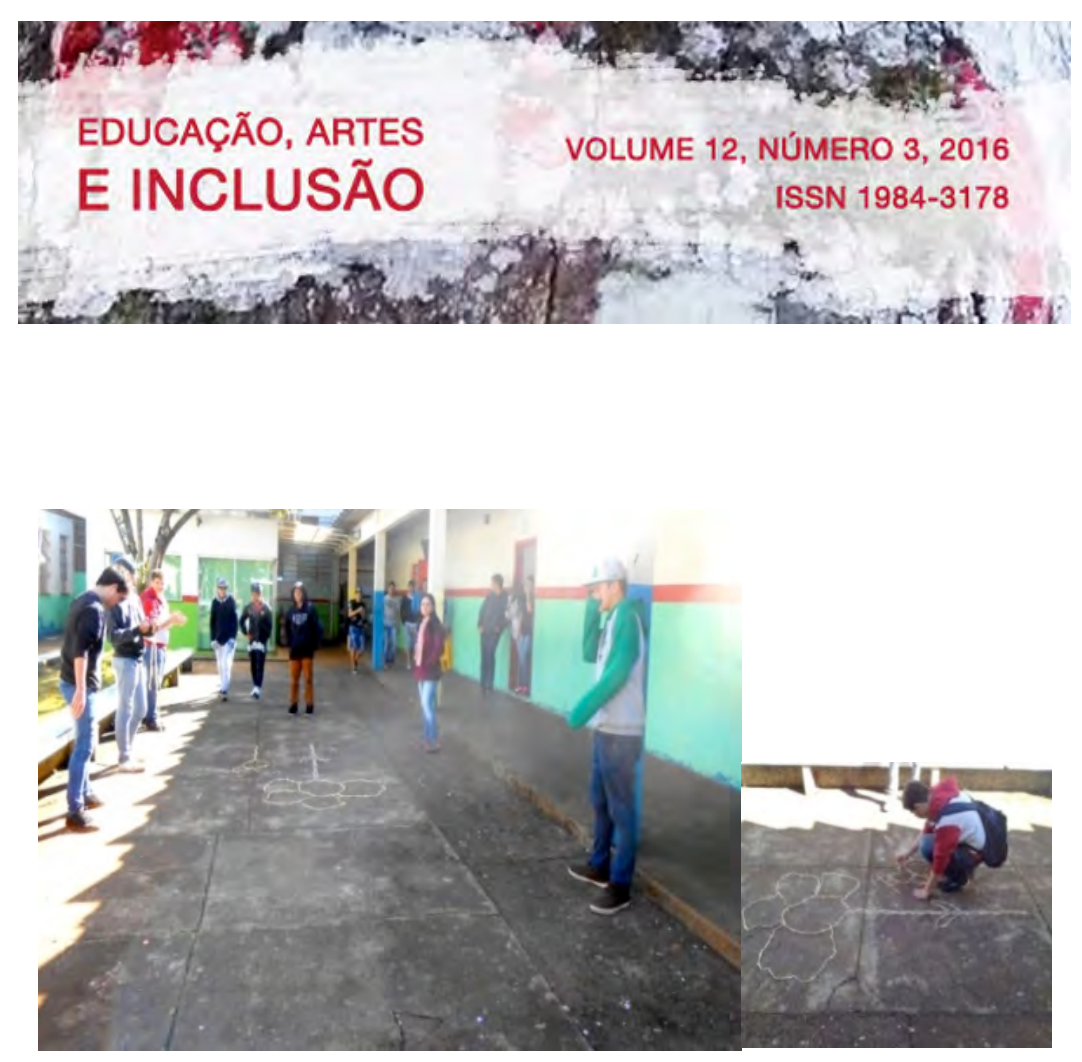

Figura 4: Momento da Performance Grupo 1.

Fonte: Acervo Pessoal (2015).

Um grupo 2 optou por fazer a performance usando a pintura corporal, os quais, usando tinta guache reproduziram flores no corpo, do mesmo modo, remetendo a produção artística de Lenice.

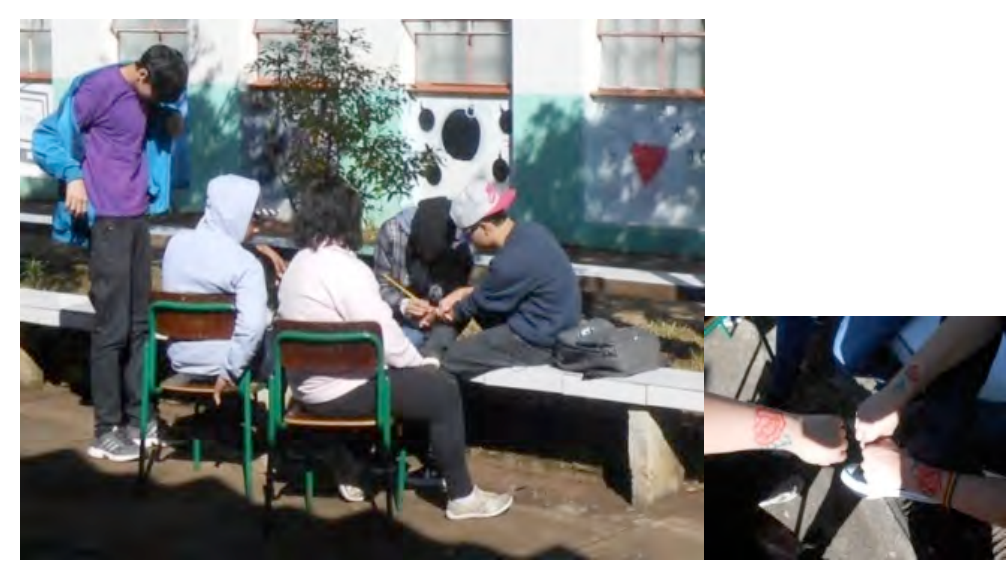

Figura 5: Momento da Performance Grupo 2.

Fonte: Acervo Pessoal (2015).

Após a realização das performances, encaminhou-se a turma de estudantes para interagir com as turmas que estavam nas salas de aula. $\mathrm{O}$ grupo 3 montou pequenas rosas de tripas, colorindo-as com tinta guache. As rosas foram colocadas em um prato, e foram 


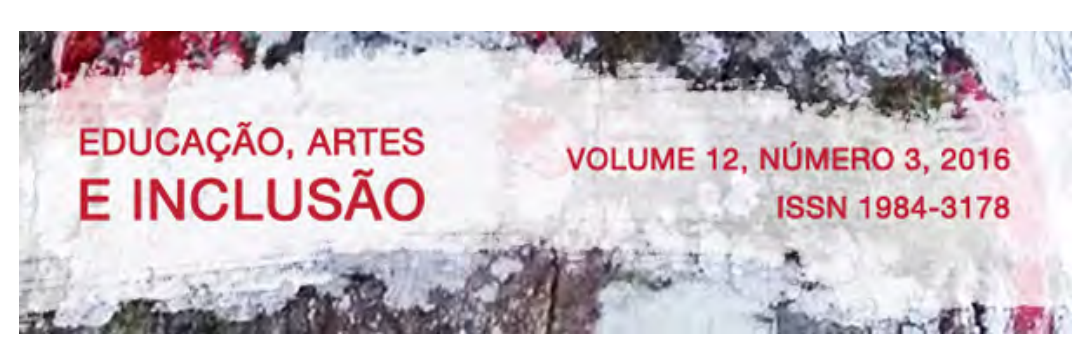

oferecidas aos estudantes e professores (Figura 6). Os/as estudante somente mencionavam o elemento tripa quando eram indagados sobre o material utilizado.

As reações dos estudantes e professores foram diversas. Alguns professores mostravam interesse, outros não, já os estudantes foram muito questionadores. Expressavam desconfiança em relação ao uso da tripa de animais no trabalho, mas pediam para cheirar e manusear os elementos e reagiam com repúdio e graça. Poucos estudantes demonstraram desinteresse pelo trabalho.

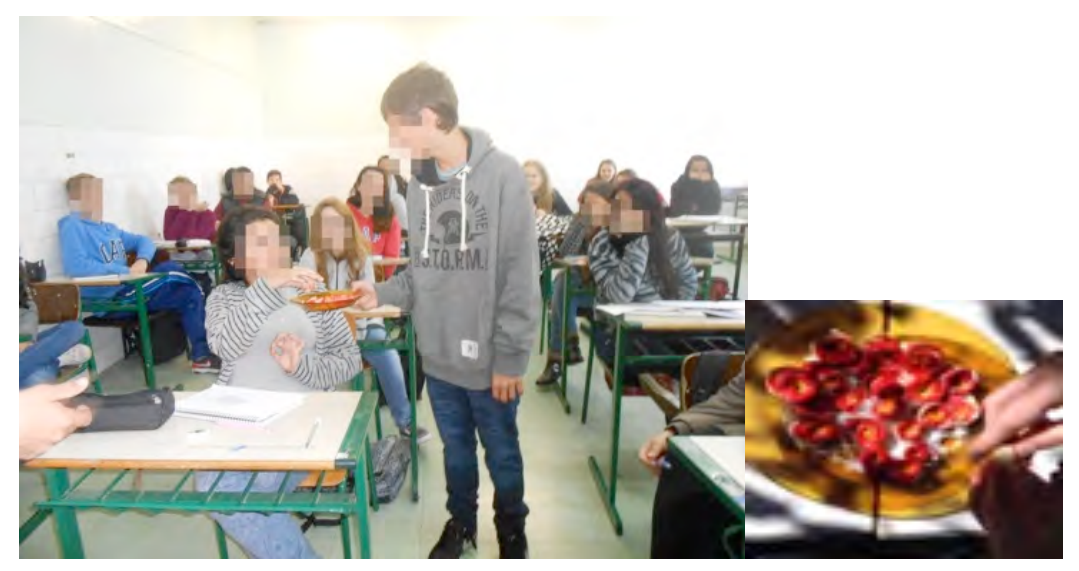

Figura 6: Happening realizado pelo grupo 3.

Fonte: Acervo Pessoal (2015).

Seguindo indicações de Barbosa (2002, p. 63) "Ainda olhamos muito pouco a produção de nossos aprendizes; ainda escutamos muito pouco o que permitimos que eles nos digam" ao voltar para a sala de aula, a leitura do fazer artístico como um "convite a pensar" (BARBOSA; CUNHA, 2010) foi contemplado. Realizou-se uma socialização dos trabalhos, avaliando os recursos utilizados, o envolvimento da turma com a experiência e as reações das interações com o 'público'.

Em relação às experiências, percebeu-se que a maioria dos/as estudantes compreendeu qual era o propósito de usar a tripa e suas percepções sobre a experiência foram maiores quando eles se confrontaram com a reação dos colegas diante do material usado. Também as reações iniciais de repúdio pela tripa foram diluídas quando se posicionaram como 'criadores' 


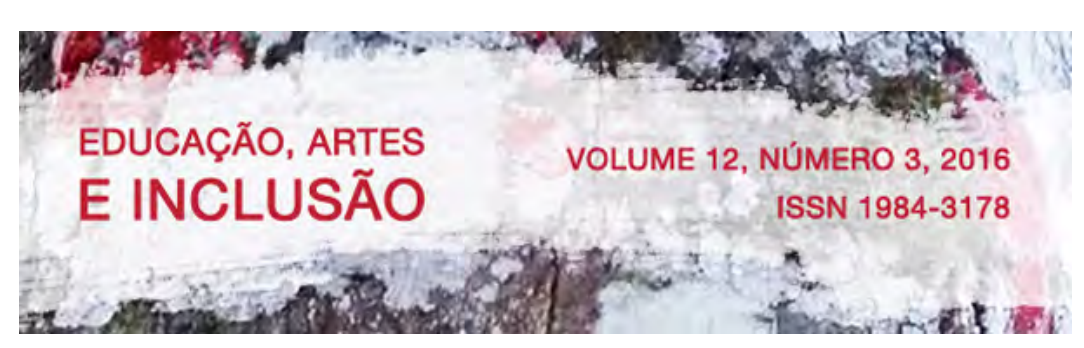

frente aos colegas de outras turmas. Ao interagir defendiam e justificavam a experiência e o material usado.

Quando a recepção pelos colegas de outras turmas, os/as estudantes deram ênfase, em seus comentários, sobre a reação de repúdio de seus colegas em relação às tripas (curiosamente, do mesmo modo quando as tripas foram apresentadas a eles/elas como elemento estético). Os comentários do 'público' foram muitos, variados e curiosos: “O que é isso?', "Porque usar isso?”, “Que cheiro ruim!". As experiências proporcionaram aos estudantes uma relação estética e artística com a tripa, fazendo-os se aproximar com a experiência da criação e recepção da obra, vivida pela artista.

É preciso perceber e analisar de que maneira as inter-relações artísticas e estéticas vem ocorrendo ao longo do processo histórico-social da humanidade. Além disso, é preciso verificar como tais relações culturais mobilizam valores, concepções de mundo, de ser humanos, de gosto e de grupos sociais. (FERRAZ; FUSARI, 1993, p.18).

Desta forma, falar da poética da artista Lenice é um modo de interagir com histórias e contextos sociais distintos, conhecendo aspectos culturais que vão se modificando, criando um novo cenário para a região. A relação da poética da artista aos aspectos do contexto regional se mostra contemplada nas atividades e intervenções.

É importante registrar que a abordagem ao contexto local, ao desenvolvimento das agroindústrias e o campo das artes possibilitou aos estudantes estabeleceram novos conhecimentos. A apresentação de um costume comum (considerado antigo) suscitou interesse e os estudos poderiam ser estendidos para novos campos de conhecimento, abrangendo outras disciplinas.

Como forma de contextualizar a questão levantada, criou-se uma imagem que ilustra o que se chamou de 'ciclo do processo de criação do porco', envolvendo o confinamento e criação, o carregamento, a comercialização de produtos de origem suína e o consumo deste animal. Há neste ciclo múltiplas possibilidades de explorar, didaticamente, todas as etapas, explorando novos conhecimentos, visões e ideias sobre a cultura da região. 


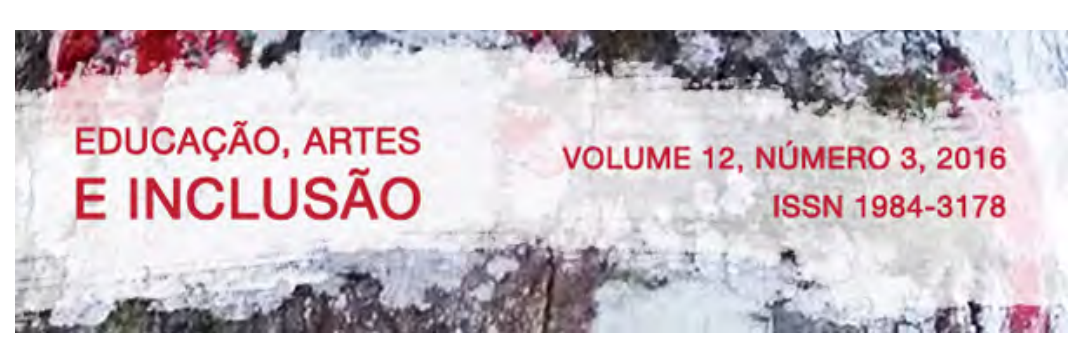

\begin{tabular}{|c|c|c|c|}
\hline A produção familiar & $\begin{array}{c}\text { Deslocamento para } \\
\text { indústria e abate }\end{array}$ & A comercialização & Consumo \\
\hline & & & \\
\hline & & & \\
\hline
\end{tabular}

Quadro 1: Ciclo do processo de criação do porco - comercialização e consumo.

Fonte: Acervo pessoal (2015).

Cada disciplina pode enfatizar aspectos referentes aos seus conteúdos curriculares e a arte tem aptidão para percorrer todas as áreas e temas, dialogando com vários campos do saber. Por meio de desenhos, pinturas, maquetes, painéis demonstrativos, performances, entre outras linguagens artísticas, levando os/as estudantes a decifrarem códigos, conhecerem conceitos e símbolos, estabelecerem relações entre arte e vida social.

\section{CONSIDERAÇÕES FINAIS}

Observou-se no decorrer das experiências a importância de abordagens que tragam as referências locais para as artes. As reflexões sobre o histórico e as contribuições culturais de diferentes grupos sociais para a região oeste foram importantes momentos de reflexão e geração de conhecimento. Também foi possível perceber que as atividades propiciaram que os/as estudantes saíssem da zona de conforto, incentivando-os a reagir às propostas e materiais apresentados.

Conforme os pressupostos da abordagem triangular Contextualizar, Fazer e Ler imagens e obras de arte, as experiências em arte-educação devem gerar novos e interessantes desafios aos professores e estudantes. Uma das características da abordagem triangular é a visão de que seus fundamentos não devem ser seguidos como um manual. 


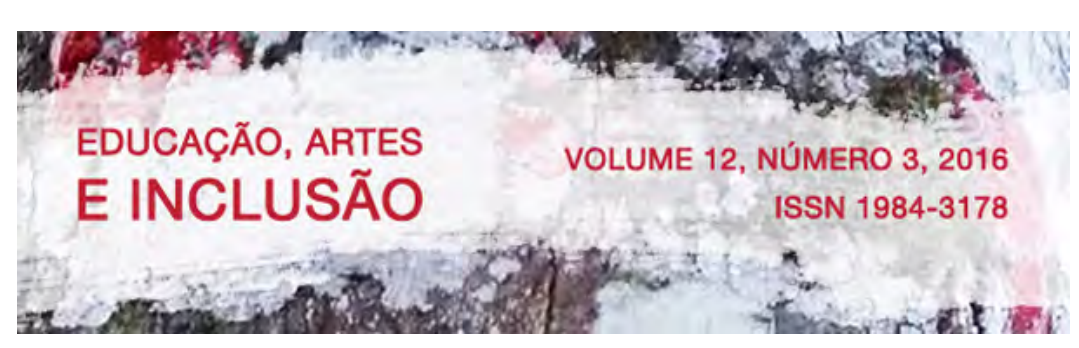

Ao contextualizar a poética da artista Lenice Weis relacionando-a ao contexto e cultura regional, a experiência em arte-educação se transforma em uma aprendizagem que rompe com os processos tradicionais. Neste sentido, no exercício da reflexão, da criação, da exposição e interação com o 'público' os/as estudantes foram incentivados a exercitar a liberdade de ação, a disposição corajosa de interagir e propor aos colegas de outras turmas novas formas de ver e pensar a arte.

Por fim, pode-se dizer que cabe ao professor de artes assumir o desafio de colocar-se em movimento, desempenhando o papel de mediador entre o conhecimento historicamente construído, o processo de ensino e a interação com os/as estudantes. Ao assumir-se como um pesquisador, articulando e organizando novas e criativas experiências artísticas e estéticas, o/a professor/a de artes gera meios de encorajar os/as estudantes a viverem experiências que os tornem protagonistas, que ampliem seus repertórios culturais, incentivando-os ao posicionamento crítico e reflexivo.

\section{REFERÊNCIAS}

BARBOSA, Ana Mae Tavares Bastos. A imagem no ensino da arte: anos 1980 e os novos tempos. 8. Ed. São Paulo: Perspectiva, 2009.

Inquietações e mudanças no ensino da arte. São Paulo: Cortez, 2002.

; CUNHA, Fernanda P. da. Abordagem Triangular no ensino das Artes e culturas visuais. São Paulo: Cortez, 2010.

BRASIL. Secretaria da Educação Fundamental. Parâmetros Curriculares Nacionais: Arte. Brasília: MEC/SEF, 1998.

CEOM. Cadernos do CEOM. Chapecó: Argos, nº 23, 2006. 352 p.

Para uma História do Oeste Catarinense: 10 anos de CEOM. Chapecó: Unoesc Universidade de Santa Catarina, 1995. 331 p.

COSTA, Claudio F. Teorias da arte. Disponível em: http://criticanarede.com/est_tarte.html acesso em 19/08/2015.

FERRAZ, Maria; FUSARI, Maria. Metodologia do ensino da arte. 2. Ed. Cortez, 1993.124p. 


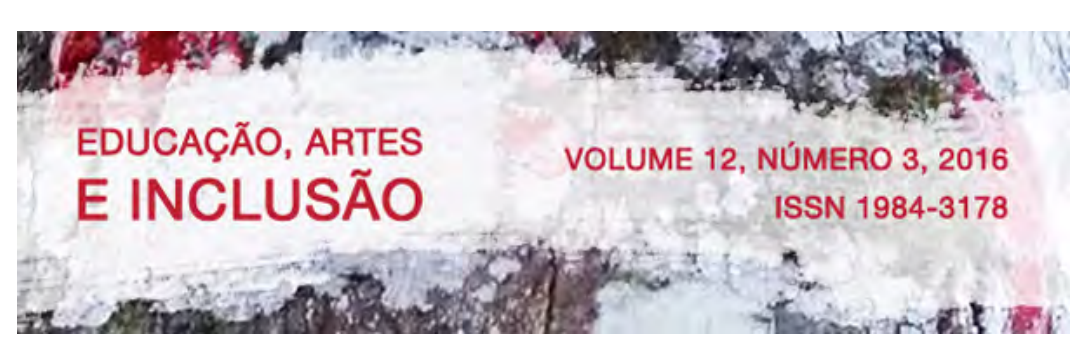

GIL, Antonio Carlos. Métodos e técnicas de pesquisa social. São Paulo: Atlas, 1999. 206 p. IOP, Elisa. Ensino das artes visuais e contexto cultural. Chapecó: UNOCHAPECÓ: FUNCITEC, 2002.

IOP, Elisa. Portfólio da artista: Lenice Weis/Artes Visuais (1987-2011).

MARCON, Telmo. Memória, história e cultura. Chapecó - SC: Argos, 2003.

MATTOS, Tarcísio. Construtores das artes Visuais. Florianópolis: Tempo Editorial, 2014.

ONGHERO, André Luiz. Retratos e memórias da história de Formosa do Sul. Chapecó: CEOM/Unochapecó, 2012.

PAREYSON, L. Os problemas da estética. 3. Ed. São Paulo: Martins Fontes, 2001.

RAMOS, Rogério de Araújo. Dicionário didático de Língua Portuguesa: ensino fundamental. 2. Ed. - São Paulo: Edições SM, 2011.

RENK, Arlene. Narrativas da diferença. Chapecó: Argos, 2004.

SANTA CATARINA. Proposta Curricular de Santa Catarina: Educação Infantil, Ensino Fundamental e Médio: Educação Infantil, Ensino Fundamental e Médio: Disciplinas curriculares. Florianópolis: COGEN, 1998.

SILVA, Edna L. Da; MENEZES, Estera M. Metodologia da pesquisa e elaboração de dissertação. Florianópolis: UFSC, 2005.

WERLANG, Alceu. A colonização do Oeste Catarinense. Chapecó: Argos, 2002.

WEIS, Lenice I. A influência da família na formação do artista: Monografia apresentada à UNOESC, como parte dos requisitos para obtenção do grau de especialista em Pós-Graduação "Lato Sensu" em Arte-Educação, sob a orientação do Professor Dr. Norberto Stori. Universidade do Oeste de Santa Catarina - UNOESC, 1997.

WEIS, Lenice. Entrevista concedida à Maria de Souza. Chapecó, 12 mar. 2014.

WEIS, Lenice. Blog de Lenice Weis. Disponível em: http://lenicew.blogspot.com.br/. Acesso em 06 de setembro de 2015. 